Sterilization of different explant types in micropropagation of CAB-6p and Gisela 6 cherry rootstock

Sterilizacija različitih tipova eksplantata u mikropropagaciji podloga trešnje CAB-6p i Gisela 6

Stanisavljević, A., Bošnjak, D., Štolfa, I., Vuković, R., Kujundžić, T., Drenjančević, $M$.

Poljoprivreda/Agriculture

ISSN: 1848-8080 (Online)

ISSN: 1330-7142 (Print)

http://dx.doi.org/10.18047/poljo.23.2.5

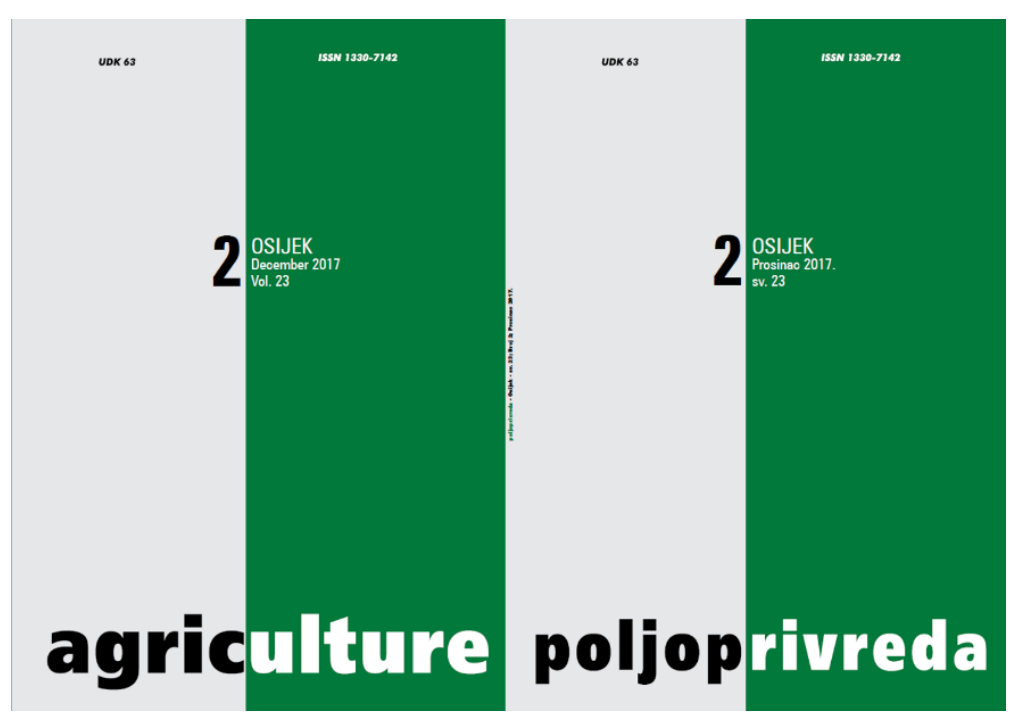

Poljoprivredni fakultet u Osijeku, Poljoprivredni institut Osijek

Faculty of Agriculture in Osijek, Agricultural Institute Osijek 


\title{
STERILIZATION OF DIFFERENT EXPLANT TYPES IN MICROPROPAGATION OF CAB-6P AND GISELA 6 CHERRY ROOTSTOCK
}

\author{
Stanisavljević, A. ${ }^{(1)}$, Bošnjak, D. ${ }^{(1)}$, Štolfa,.$^{(2)}$, Vuković, R. ${ }^{(2)}$, Kujundžić, $T^{(1)}$, Drenjančević, M. ${ }^{(1)}$
}

\author{
Original scientific paper \\ Izvorni znanstveni članak
}

\section{SUMMARY}

Research with the objective of finding efficient (non residual) sterilants for the purpose of greater automatization in establishing aseptic in vitro tissue culture was conducted on cherry rootstocks CAB 6 P and Gisela 6. Two ways of sterilization were examined $\left(\mathrm{NaOCl}\right.$ and ozone $\mathrm{O}_{3}$ ) through survival rate on three types of explants; buds with primordial leaves, buds without primordial leaves and nodal non lignified segment with axillary buds. Ozone resulted with the high rate of survival (from 57 to 93\%) regardless of the type of explants and the rootstock variety. By introducing a complete bud without destruction significantly resulted with the higher rate of survival (from 90 to $97 \%$ ). Results indicate the potential for ozone sterilization of the starting material not only as an ostensible but the perforated (sub-cuticular transpiration) agent.

\section{Key-words: in vitro, CAB-6P, Gisela 6, sterilization, ozone}

\section{INTRODUCTION}

In recent years, in the Republic of Croatia a lot of efforts have been made to improve the culture of plant cells and tissues like the improvement of existing methods, the creation of virus free planting material, accelerated clonal reproduction and different possibilities of micropropagation of common fruit rootstocks (Tančeva Crmarić et al., 2012; Dorić et al., 2015).

Micropropagation is a modern procedure that has been used for more than thirty years and is increasingly being used in nursery production of planting material, especially in the production of fruit rootstocks, including cherry (Sedlák et al., 2008). The presence of pathogens in crops usually results in increased mortality of culture. According to Constantine (1986), Buckley and Reed (1994) surface sterilization or removal of exogenous and endogenous plant pathogens that could contaminate substrate environment while introducing explants in vitro culture, represents the key to the success of in vitro culture.

Leifert et al. (1989 and 1994) state that the loss due to in vitro contamination primarily by fungi, bacteria and mold in most commercial and scientific laboratories for tissue culture is an average of $3-15 \%$ per each subcul- ture. Mihaljević et al. (2013) indicate a good potential of silver nitrate $\left(\mathrm{AgNO}_{3}\right)$, calcium hypochlorite $\left(\mathrm{Ca}(\mathrm{ClO})_{2}\right)$ and mercury (II) chloride $\left(\mathrm{HgCl}_{2}\right)$ in the sterilization of "Oblačinska" sour cherry explants. As a standard, the most laboratories for surface sterilization of explants use conventional methods and agents (sodium or calcium hypochlorite, ethanol and/or antibiotics), although these chemical methods are often not sufficient to ensure sterile conditions.

Ozone $\left(\mathrm{O}_{3}\right)$ is a powerful natural oxidant and the strongest commercially available disinfectant that is very effective in destroying odors, bacteria, viruses and other microorganisms (Wysok et al., 2006). Ozone has a very strong antibacterial power. It has a very short half-life in water and soil, oxidizes other compounds or dissolves in the diatomic molecular oxygen without leaving toxic residues (Ebihara et al., 2012; Horvitz and Cantalejo 2014; Miller et al., 2013).

(1) Assoc. Prof. Aleksandar Stanisavljević (astanis@pfos.hr); Dejan Bošnjak, M. Eng. Agr., Toni Kujundžić, M. Eng. Agr., assist. Prof. Mato Drenjančević - Josip Juraj Strossmayer University of Osijek, Faculty of Agriculture in Osijek, Ulica Vladimira Preloga 1, 31000 Osijek, Croatia, (2) Assist. Prof. Ivna Štolfa, Assist.Prof. Rosemary Vuković - Josip Juraj Strossmayer University of Osijek, Department of Biology, Cara Hadrijana 8/A, 31000 Osijek, Croatia 
Some recent research indicates great potential use of ozone $\mathrm{O}_{3}$ in the micropropagation of plant material (Luna et al., 2009; Cardarelli et al., 2014). Also, according to Štolfa et al. (2014) ozone application possibly destroyed ethylene which is produced by dissection of plant tissue and can be very harmful to many fruits, vegetables, flowers and plants by accelerating the aging process.

The aim of this research is focused on the highest possible automation of the process of introducing starting material in vitro, or finding more efficient (nonresidual) sterilants.

\section{MATERIAL AND METHODS}

The study was conducted on vegetative explants (buds and nodial segments) of cherry rootstock CAB 6P (A1) and Gisela 6 (A2) collected from mother plants in February 2016, planted in 10 liter pots from protected greenhouse.

These two rootstocks are mainly used for contemprary high density cherry orchards. CAB $6 \mathrm{P}$ represents a biotype of Prunus cerasus (cv 'Marasca di Vigo') selected by the University of Bologna. Along with all positive attributes (good grafting compatibility, dwarfing habit of $30 \%$, good adaptation to heavy soils with low permeability, resistance to calcareous soils above $9 \%$ active lime), it is an excellent choice for replant soils (resistant to nematodes, medium sensitive to Armillaria mellea, tolerant to Phytophtora cactorum and Verticillium dahliae; slightly sensitive to Agrobacterium tumefaciens). Gisela 6 is a hybrid of Prunus cerasus x Prunus canescens from Giessen (Germany). Depending on orchard management and soil fertility, vigour is $30-50 \%$ lower than standard Prunus avium seedlings. It is quite tolerant to crown gall (Agrobacterium tumefaciens), but otherwise under humid conditions it is sensitive to root rot (Armillaria mellea), collar rot (Phytophtora cactorum) and bacterial canker (Pseudomonas syringae). Both of them are superior in terms of impact on fruit quality because, according to Hrotkó et al. (2014), those rootstocks provide a balanced nutrient supply.

The collected material was washed with distilled water and stored in the refrigerator for 24 hours at $4^{\circ} \mathrm{C}$. The study used two treatments of surface sterilization on three types of explants. Types of explants include: buds without primordial leaves (B1), buds with primordial leaves (B2) and (B3) nodal $1.5 \mathrm{~cm}$ long unlignified segment with one axillary bud (Figure 1). Meristem dissection of primordial leaves (B1) was conducted under the stereomicroscope (Nikon SMZ1000).
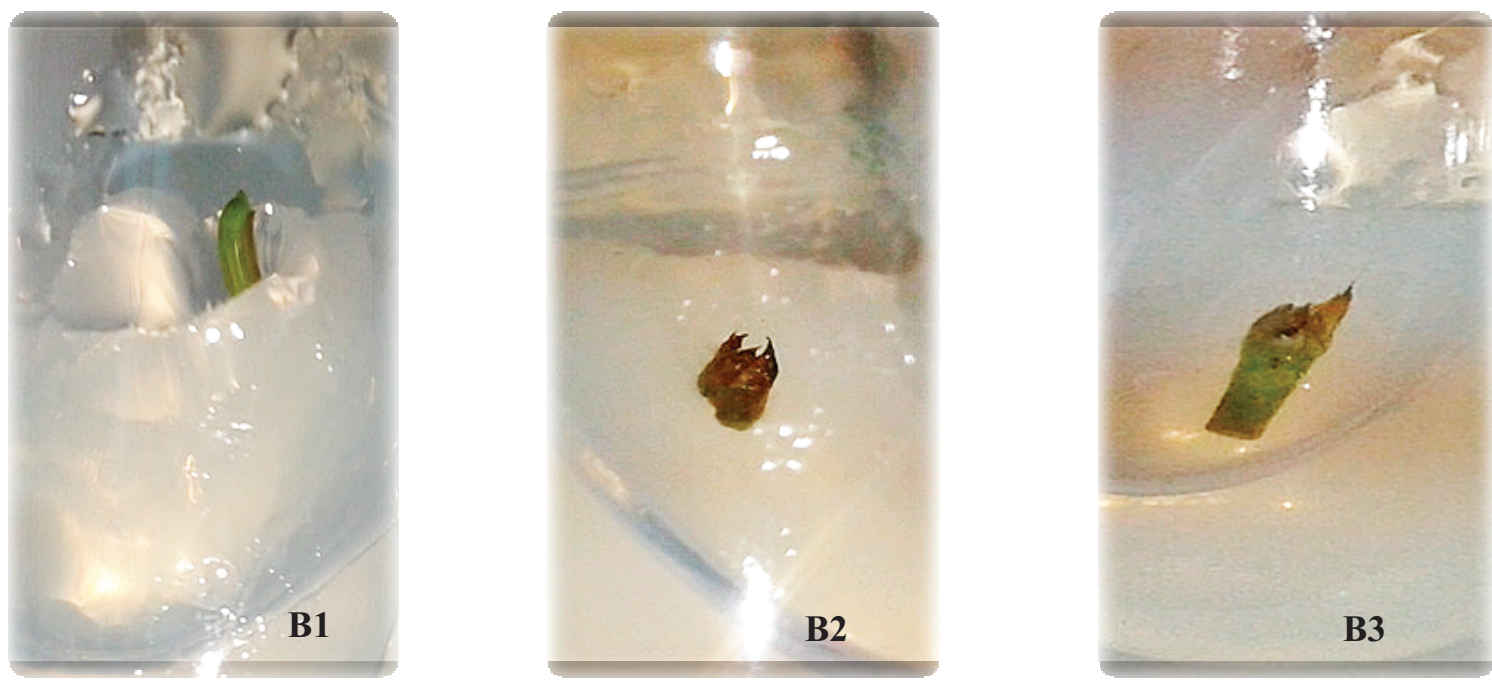

Figure 1. Type of explants (B): B1 - without primordial leaves, B2 - with primordial leaves, B3 - nodal explants Slika 1. Tip eksplantata (B): B1 - bez primordijalnih listova, B2 - s primordijalnim listovima, B3 - nodijalni eksplantati

Surface sterilization of explants was carried out with sodium hypochlorite $(\mathrm{NaOCl})$ as standard treatment (C1) and ozone $\mathrm{O}_{3}$ (C2). Workspace (laminar flow hood) was treated with the UV lamp for 2 hours, and working surface with $95 \%$ ethanol.

The first type (treatment) of sterilization explants was carried out in a solution of $10 \%$ sodium hypochlorite ( $\mathrm{NaOCl} 20 \mathrm{ml} / 200 \mathrm{ml}$ water - C1) with the addition of surfactant Tween $80(0.1 \%)$. Surfactant has the purpose of reducing surface tension and increasing the contact of surface. Buds were submerged in this solution for 20 minutes, and then washed with $70 \%$ ethanol and sterilized water three times. The explants were inoculated on semisolid culture media under binocular.

The second type of surface sterilization (C2) was carried out by ozone generator (Tiens, model TR-YCA Tianji Tianshi Group Co., Ltd., max. $150 \mathrm{mg} / \mathrm{h} \mathrm{O}_{3}$ ). Explants were first pre-washed three times under water, followed by immersion in a container with demineralized water where $\mathrm{O}_{3}$ was injected for 40 minutes. The explants were then rinsed in $70 \%$ ethanol for three minutes and sterilized water three times. 
A semisolid culture medium for the inoculation of the explants contained the combination of MS micronutrients and vitamins (Murashige and Skoog, 1962), macro nutrients SH (Schenk and Hildebrandt, 1972), sugar $(30 \mathrm{~g} / \mathrm{l})$, agar $(6.5 \mathrm{~g} / \mathrm{l})$ and plant hormones such as 6-benzylaminopurine (BA $0.05 \mathrm{mg} / \mathrm{l})$, 1-naphthaleneacetic acid (NAA $0.001 \mathrm{mg} / \mathrm{l}$ ) and gibberellic acid $\left(\mathrm{GA}_{3} 0.5 \mathrm{mg} / \mathrm{l}\right)$. The $\mathrm{pH}$ of the medium was set up to $\mathrm{pH}$ 5.8. The medium was sterilized in an autoclave for 20 minutes at $121^{\circ} \mathrm{C}$ and pressure of 1.2 bars.

The plant material was introduced into test tubes with $10 \mathrm{ml}$ of culture medium. During the stabilization phase, the explants were cultured for 30 days at $25 \pm$ $2^{\circ} \mathrm{C}$ and photoperiod of 16 hours of light and 8 hours of darkness. After 30 days the numbers of healthy, contaminated and non-viable (dead) explants were established.

Each treatment was set in three repetitions, each repetition contained ten test tubes with growth media containing one explant. All results were analysed with statistical data processing by SAS Software 9.3, (20022010, SAS Institute Inc., Cary, USA) and Microsoft Office Excel 2010. The following statistical methods were used: analysis of variance (ANOVA), statistical tests of significance influence of the applied treatment - F test and Fisher's LSD test (eng. Least Significant Difference) $(p \leq 0.05)$.

\section{RESULTS AND DISCUSSION}

Factor $B$ (type explants), and the interaction of factors $A x B \times C$ (rootstock $x$ explant $x$ sterilants), significantly influenced on the number of healthy $\left(B-23.63^{*}\right.$; AxBxC - 5.58*) and contaminated (B - 32.17*; AxBxC - 4.89*) explants (Table 1). Factor B (type of explants, $6.50^{*}$ ) significantly affected the number of non-viable explants.

The remaining interaction $(A x B, A x C$ and $B \times C)$, factor $A$ (rootstock) and factor $C$ (sterilants) had no significant effect on the number of healthy, contaminated and non-living explants. Explants type B2 (with primordial leaves) resulted in significantly higher number of healthy (3.15A) explants, and significantly less contaminated (0.91B) ones. A significantly higher number of non-living explants was found with explants where primordial leaves were removed (B1 - 1.01).

Table 1. Tree-way ANOVA for the number of healthy, contaminated and dead in vitro explants under the influence of the rootstock (A), type of explants (B) and sterilizing agent (C)

Tablica 1. Trofaktorijalna ANOVA za broj zdravih, kontaminiranih i neživih in vitro eksplantata pod utjecajem podloge (A), tipa eksplantata (B) i sterilizanta (C)

\begin{tabular}{|c|c|c|c|c|c|c|c|}
\hline & A & B & C & $A \times B$ & $A \times C$ & B $\times$ C & $A \times B \times C$ \\
\hline & \multicolumn{7}{|c|}{ F test } \\
\hline Healthy (Živi) & ns & $23.63^{*}$ & ns & ns & ns & ns & $5.58^{*}$ \\
\hline B1 & & $2.32^{B}$ & & & & & \\
\hline B2 & & $3.15^{A}$ & & & & & \\
\hline B3 & & $2.63^{B}$ & & & & & \\
\hline Contaminated (Kontaminirani) & ns & $32.17^{*}$ & ns & ns & ns & ns & $4.89^{*}$ \\
\hline B1 & & $1.77^{A}$ & & & & & \\
\hline B2 & & $0.91^{B}$ & & & & & \\
\hline B3 & & $1.97^{A}$ & & & & & \\
\hline Dead (Neživi) & ns & $6.50^{*}$ & ns & ns & ns & ns & ns \\
\hline B1 & & $1.01^{\mathrm{A}}$ & & & & & \\
\hline B2 & & $0.79^{\mathrm{B}}$ & & & & & \\
\hline B3 & & $0.71^{\mathrm{B}}$ & & & & & \\
\hline
\end{tabular}

Treatment means with the same letter do not differ after LSD test: A, B p $\leq 0.05^{*}$; ns - not significant

RO0TSTOCK CAB 6P - Type B2 explants (with primordial leaves) of the rootstock CAB-6P (A1) resulted in a significantly higher rate of healthy (B2/C1 - 97\% and $\mathrm{B} 2 / \mathrm{C} 2-93 \%$ ) explants and considerably lower rate of contaminated (B2/C1 - $0 \%$ and $\mathrm{B} 2 / \mathrm{C} 2-3.5 \%)$ ones (Figure 2) on both versions of sterilization (Table 2). No significant difference was determined in the number of healthy and contaminated explants between B1 and B3 on both methods of sterilization (Table 2). Comparing the effect of $\mathrm{NaOCl}$ on survival ( $80 \%$ of healthy) of explants of "Oblačinska" sour cherry Mihaljević et al. (2013), our research showed $\mathrm{NaOCl}$ to be more efficient with a survival rate of $97 \%$ (A1/C1/B2). Vujović et al. (2012) reported the results of contamination of explants Jaspi ${ }^{\circledR}$ Fereley (rootstock of plums) sterilized with $\mathrm{NaOCl}$ of $48.1 \%$, which represents a higher percentage compared to all of our variants $(0-40 \%)$. After 30 days on the variant B3 (nodal segments), the percentage of healthy explants was $\mathrm{C} 1-60 \%$, which is better in comparison to the results obtained from micropropagation of nodal segments in the 
research Luna et al. (2003) on Ilex Dumosa (38\%), i.e. the results obtained by Yildirim et al. (2011) on nodial segments of apricots "Hacıhaliloğlu" (7.20 - 54.65\%). Luna et al. (2003) in their research on nodal micropropagation of $l$. Dumosa found contamination state (2-13\%) after 30 days to be relatively low. Darkening (browning) of the explants is defined as an influence of the concentration of sucrose present in the medium $\left(7.5-30 \mathrm{~g} / /^{-1}\right)$, which resulted in $87-100 \%$ healthy explants. Sansberro et al. (2001) state the opposite; the browning in most cases resulted from dying and necrosis, but also greatly increased microbiological contamination. We consider that the established differences in the survival or contamination percentage

\section{CAB-6P (A1/C1 ) NaOCl}

$\square \mathrm{B} 1 \square \mathrm{B} 2 \square \mathrm{B} 3$

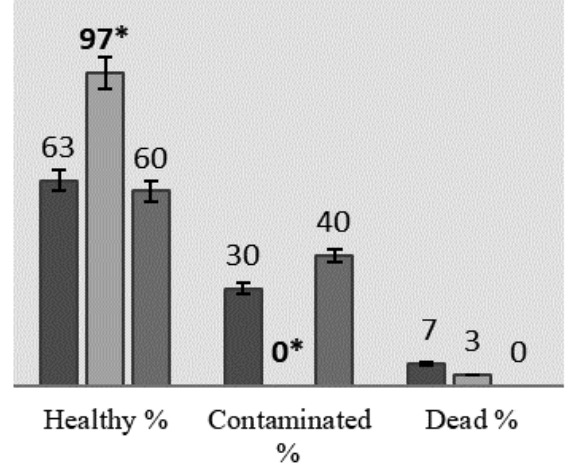

are largely the result of initial contamination whose effect by sterilization has not been achieved. In addition to the differences in the morphogenic stage of development or age of the selected explants, great attention must also be given to the careful preparation and selection of the donor plant. Time of the explants introduction in in vitro culture also shows significant differences between seasons (donor sampling time) that was emphasized by the Bernasconi et al. (1998). In our research, we did not determine statistical differences between sterilizants by the types of explants in the parameter number of nonviable explants. Mortality rates in both sterilants ranged from 0 (B3) $3-3.5$ (B2) to a maximum of $7 \%$ (B1).

\section{CAB-6P(A1/C2) Ozone}

$\square \mathrm{B} 1 \square \mathrm{B} 2 \square \mathrm{B} 3$

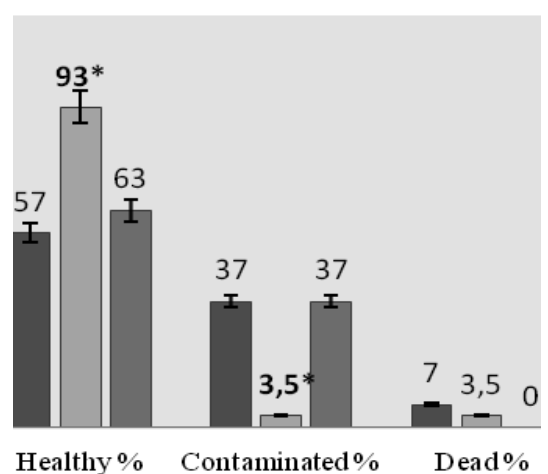

Figure 2. Influence of different sterilizing agents (C) on the rate of healthy, contaminated and dead explants (\%) of rootstock CAB-6P (A1)

Grafikon 2. Utjecaj različitih sterilizanata (C) na udio živih, kontaminiranih i neživih eksplantata (\%) kod podloge CAB-6P (A1)

Another method of sterilization by ozone $\mathrm{O}_{3}(\mathrm{C} 2)$ also resulted in significantly higher rate of healthy explants with identical $97 \%$ on type B2 (A1/C1/B2), i.e. a considerably lower rate of contaminated explants $(3.5 \%$, Figure 2.). Type B3 resulted in $63 \%$ and type B1 with $57 \%$ survived explants between which there is no significant difference. Comparing the rate of healthy and contaminated explants on "Oblačinska" cherry, Mihaljević et al. (2013) indicated the best results of sterilization by silver nitrate - $\mathrm{AgNO}_{3}$ (96.67\% healthy and $3.3 \%$ contaminated explants). Ozone sterilization in our research resulted in a very similar rate of healthy and contaminated explants in variant B2 (97\% and 3.5\%). Comparing the results of Yildirim et al. (2011) by the contamination of sterilized nodal explants with $\mathrm{NaOCI}(6.01$ to $33.18 \%)$ and survival rate $(7.20-54.65 \%), B 3$ influenced with ozone treatments resulted in higher contamination rate $(67 \%)$ but also higher rate of healthy explants $(63 \%)$. There is no significant difference between the explants in the rate of mortality in our research (Figure 2). The highest mortality rate was observed in the type B1 with 7\%, following B2 with $3.5 \%$, while at nodal segment there was no mortality $(0 \%)$.

Table 2. Effects of sterilizing agent $\mathrm{C} 1$ and $\mathrm{C} 2$ on the average number of healthy, contaminated and dead explants (B) at CAB-6P rootstock

Tablica 2. Efekt sterilizanta C1 i C2 na prosječan broj zdravih, kontaminiranih i neživih eksplantata (B) kod podloge CAB-6P

\begin{tabular}{|c|c|c|c|c|c|c|}
\hline \multirow{3}{*}{$\frac{A}{C}$} & \multicolumn{6}{|c|}{ CAB-6P (A1) } \\
\hline & \multicolumn{3}{|c|}{ C1 } & \multicolumn{3}{|c|}{ C2 } \\
\hline & $\begin{array}{l}\text { Healthy } \\
\text { (Zdravi) }\end{array}$ & $\begin{array}{l}\text { Contaminated } \\
\text { (Kontaminirani) }\end{array}$ & $\begin{array}{c}\text { Dead } \\
\text { (Neživi) }\end{array}$ & $\begin{array}{l}\text { Healthy } \\
\text { (Zdravi) }\end{array}$ & $\begin{array}{l}\text { Contaminated } \\
\text { (Kontaminirani) } \\
\end{array}$ & $\begin{array}{c}\text { Dead } \\
\text { (Neživi) }\end{array}$ \\
\hline B1 & $2.60^{B}$ & $1.81^{\mathrm{A}}$ & 1.05 & $2.48^{\mathrm{B}}$ & $2.04^{\mathrm{A}}$ & 1.05 \\
\hline B2 & $3.19^{A}$ & $0.71^{\mathrm{B}}$ & 0.88 & $3.13^{\mathrm{A}}$ & $0.88^{\mathrm{B}}$ & 0.88 \\
\hline B3 & $2.54^{\mathrm{B}}$ & $2.11^{\mathrm{A}}$ & 0.71 & $2.60^{\mathrm{B}}$ & $2.01^{\mathrm{A}}$ & 0.71 \\
\hline $\mathrm{F}$ test & 8.72 & 13.24 & 1.50 & 10.28 & 14.93 & 1.50 \\
\hline$p \leq 0.05$ & 0.0168 & 0.0063 & 0.2963 & 0.0115 & 0.0047 & 0.2963 \\
\hline
\end{tabular}

${ }^{*} \mathrm{~A}$ - rootstock; $\mathrm{C}$ - sterilizing agent $\left(\mathrm{C} 1-\mathrm{NaOCl}, \mathrm{C} 2-\mathrm{O}_{3}\right) ; \mathrm{B}$ - type of explants $(\mathrm{B} 1$ - bud with removal of the primordial leaves, $\mathrm{B} 2$ - without removing the primordia leaves, B3 - nodal fragment); ANOVA - F test; ${ }^{A, B}$ means with different letters are significantly different after $L S D$ test, $p \leq 0.05$ 
ROOTSTOCK GISELA 6 - Explants with primordial leaves (B2) at both sterilization treatments (C1 and C2) on Gisela 6 (A2) produced the highest rate of healthy $(93 \%)$, the least contaminated $(7 \%)$ and no dead $(0 \%)$ explants (Figure 3). At sterilization with $\mathrm{NaOCl}$ (C1, Table 3 ), a significant difference was confirmed on the rate of the healthy explants $(B 2,3.13$ and $B 3,2.79)$ in relation to the type B1 (2.34B). Between the types B2 and B3 significant differences were not established among the number of healthy explants. Šiško M. (2011) points out that far better results were achieved at healthy rate of Gisela 5 rootstock explant with dichloroisocyanuric acid - DICA (93.3\%) instead of $\mathrm{NaOCl}$ sterilization (57.1\%). Comparing these results, we conclude that the $\mathrm{NaOCI}$ $(C 1,93 \%)$ with ozone $(C 2,93 \%)$ in our study had a better effect in the sterilization of Gisela 6 explants (A2). After 30 days of observation (inoculation phase), we found a considerably better percentage of healthy explants (C1, $73 \%$ ) on B3 (nodal segment) compared to the similar research obtained by nodal explants micropropagation of Ilex dumosa, 38\% (Luna et al., 2003) and in apricot, $54.65 \%$ (Yildirim at al., 2011).
Significantly, a lower rate of contaminated explants (Table 3 ) in the sterilization with $\mathrm{NaOCl}$ (C1) on the roostock A2 was obtained in the type of explants where primordial leaves were not removed (B2 - 0.99B). Vujović et al. (2012) in their study on Gisela 6 for sterilization $\mathrm{NaOCl}$ contamination emphasize $88.3 \%$ as very high. The contamination identified in our research was maximally $43 \%$ (B1). The conditions in which the parent plant grew greatly affected the rate of contamination, so according to Hartmann and Kester (1983), a parent plant should be grown in a greenhouse in conditions of low humidity where we avoid excessive wetting and where contamination with pests and diseases it is not possible. Muna et al. (1999) considered that the sodium hypochlorite $(\mathrm{NaOCl})$ is more effective on the mother plants grown in the greenhouse because of their weaker and more sensitive cuticle. Šiško (2011) in their research points out that the mortality rate was $42.9 \%$ on rootstock Gisela 5 with $\mathrm{NaOCl}$ sterilization, while the rate of nonviable explants in our study ranged from $0 \%(B 2, B 3)$ to a maximum of $7 \%$ in the variant B1 (Figure 3).

\section{Gisela 6 (A2/C1) NaOCl}

$\square \mathrm{B} 1 \square \mathrm{B} 2 \square \mathrm{B} 3$

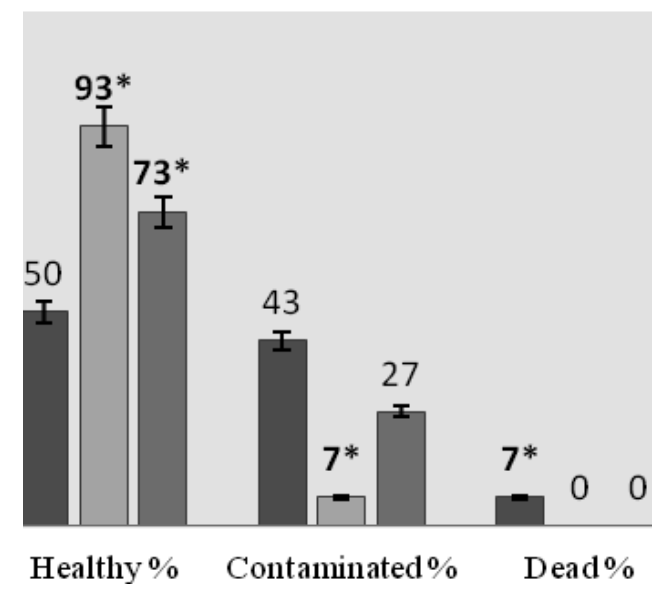

\section{Gisela 6 (A2/C2) Ozone}

$\square \mathrm{B} 1 \square \mathrm{B} 2 \square \mathrm{B} 3$

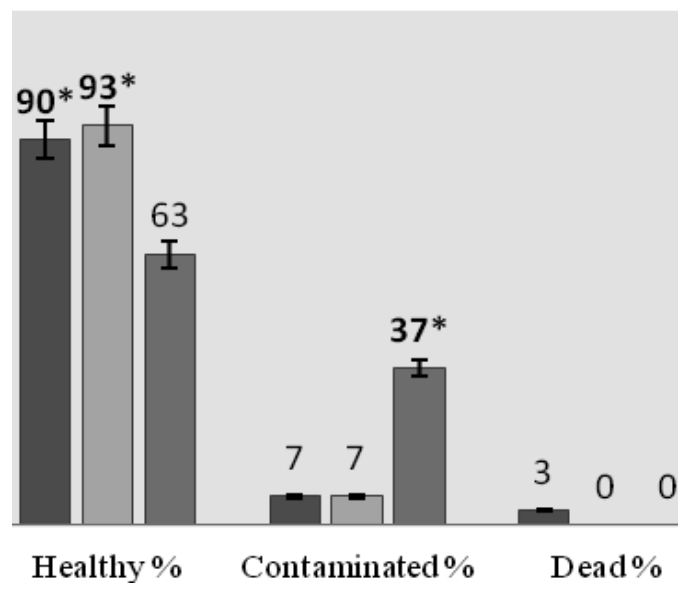

Figure 3. Influence of different sterilizing agents (C) on the rate of healthy, contaminated and dead explants (\%) of rootstock Gisela 6 (A2)

Grafikon 3. Utjecaj različitih sterilizanata (C) na udio živih, kontaminiranih i neživih eksplantanata (\%) kod podloge Gisela 6 (A2)

Sterilants C2 (ozone) resulted in a significantly higher rate of the healthy types B1 $(90 \%)$ and B2 $(93 \%)$, while type B3 resulted in $63 \%$ of explants survived (Table 3 , Figure 3$)$. A significantly higher rate of contamination was obtained in type B3 - $37 \%$, while the types B1 following the $\mathrm{B} 2$ resulted in the contamination rate of only $7 \%$. In the variants B2 and the B3 there were no records of dead explants $(0 \%)$, while in the type $\mathrm{B} 2$, the mortality rate was only $3 \%$. Comparing these results with those previously presented in research by Šiško (2011), Vujović et al. (2012) and Mihaljević et al. (2013), ozone treatment in our study resulted in a higher rate of healthy explants (C2/B1; C2/B2) and the less contaminated (C2/B1; C2/ B2) ones. 
Table 3. Effects of sterilizing agent $\mathrm{C} 1$ and $\mathrm{C2}$ on an average number of healthy, contaminated and dead explants (B) at Gisela 6 rootstock

Tablica 3. Efekt sterilizanta C1 i C2 na prosječan broj zdravih, kontaminiranih i neživih eksplantata (B) kod podloge Gisela 6

\begin{tabular}{|c|c|c|c|c|c|c|}
\hline A & \multicolumn{6}{|c|}{ Gisela 6 (A2) } \\
\hline \multirow[b]{2}{*}{ C } & \multicolumn{3}{|c|}{ C1 } & \multicolumn{3}{|c|}{ C2 } \\
\hline & $\begin{array}{l}\text { Healthy } \\
\text { (Zdravi) }\end{array}$ & $\begin{array}{l}\text { Contaminated } \\
\text { (Kontaminirani) }\end{array}$ & $\begin{array}{l}\text { Dead } \\
\text { (Neživi) }\end{array}$ & $\begin{array}{l}\text { Healthy } \\
\text { (Zdravi) }\end{array}$ & $\begin{array}{l}\text { Contaminated } \\
\text { (Kontaminirani) }\end{array}$ & $\begin{array}{c}\text { Dead } \\
\text { (Neživi) }\end{array}$ \\
\hline B1 & \multirow{3}{*}{$\begin{array}{l}2.34 B \\
3.13 A \\
2.79 A\end{array}$} & \multirow{3}{*}{$\begin{array}{l}2.19 \mathrm{~A} \\
0.99 \mathrm{~B} \\
1.76 \mathrm{~A}\end{array}$} & \multirow{3}{*}{$\begin{array}{l}1.05 \mathrm{~A} \\
0.71 \mathrm{~B} \\
0.71 \mathrm{~B}\end{array}$} & \multirow{3}{*}{$\begin{array}{c}3.08 \mathrm{AB} \\
3.13 \mathrm{~A} \\
2.59 \mathrm{~B}\end{array}$} & \multirow{3}{*}{$\begin{array}{l}1.05 B \\
1.05 B \\
2.00 A\end{array}$} & \multirow{3}{*}{$\begin{array}{l}0.88 \\
0.71 \\
0.71\end{array}$} \\
\hline B2 & & & & & & \\
\hline B3 & & & & & & \\
\hline $\begin{array}{c}\mathrm{F} \text { test } \\
\mathrm{p} \leq 0.05\end{array}$ & $\begin{array}{c}11.35 \\
0.0091\end{array}$ & $\begin{array}{c}8.97 \\
0.0157\end{array}$ & $\begin{array}{c}4.00 \\
0.0787\end{array}$ & $\begin{array}{c}4.43 \\
0.0658\end{array}$ & $\begin{array}{c}6.34 \\
0.0332\end{array}$ & $\begin{array}{c}1.00 \\
0.4219\end{array}$ \\
\hline
\end{tabular}

${ }^{*} \mathrm{~A}$ - rootstock; $\mathrm{C}$ - sterilizing agent $(\mathrm{C} 1$ - NaOCl, $\mathrm{C} 2$ - Ozone); $\mathrm{B}$ - type of explants (B1 - bud with removal of the primordial leaves, $\mathrm{B} 2$ - without removing the primordial leaves, B3 - nodal fragment)

ANOVA - $F$ test; $A, B$ means with different letters are significantly different after LSD test, $p \leq 0.05$

\section{CONCLUSION}

Micropropagation success largely depends not only on the genetic potential and the morphogenetic stages of the development or age of selected explants, but primarily on healthy and physiological status of the plant donor. The most important phase of introducing the culture before the multiplication ultimately assumes the establishment of aseptic conditions. Results of this study indicate the potential for ozone sterilization of the starting material compared with $\mathrm{NaOCl}$. At the level of the whole experiment, ozone has produced a high rate of survival regardless of the type of explants by the type of substrate. The introduction of a comprehensive bud without further destruction by removing the primordial leaves significantly and highly resulted in higher survival rates, i.e. in a low percentage of contamination. Nodal segment resulted in a satisfactory rate of healthy explants but also in significant contamination. Therefore, the necessity of finding more efficient (non-residual) sterilants is even more important in terms of greater automation of the process of introducing starting material in vitro. Results of the sterilization process indicate the need for further testing of ozone as a potential sterilization agent, not only for the surface but also as the thrusting (subcultural) agent. In addition, it needs to be examined by its curative options in case of subsequent contamination. At the level of the whole experiment, there were no statistically significant differences between the tested parameters observed on the rootstock. In this case, we cannot dismiss the possibility that the results were influenced by phylogenetic heterogeneity of plant material and plant health status of the donor.

\section{REFERENCES}

1. Buckley, P.M., Reed, B.M. (1994): Antibiotic susceptibility of plant associated bacteria. Hort. Sci., 29: 434.

2. Bernasconi, N.C., Mroginski, L.A., Sansberro, P.A., Rey, H.Y. (1998): Micropropagación de la yerba mate (Ilex paraguariensis St. Hil.): efectodelgenotipo y de la época del año en el establecimiento in vitro de los explantes. Phyton, 62: 95-99.

3. Cardarelli, M., Cardona, Suárez, C.M., Colla, G. (2014): Influence of ozone treatments on in vitro propagation of
Aloe barbadensis in continuous immersion bioreactor. Industrial Crops and Products, 55: 194-20.

doi: http://dx.doi.org/10.1016/j.indcrop.2014.02.020

4. Constantine, D.R. (1986): Micropropagation in the commercial environment. In: Withers, L., Alderson, P.G. (Eds.), Plant tissue culture and its agricultural applications. Butterworth, London, pp. 175-186.

5. Dorić, D., Ognjanov, V., Barać, G., Ljubojević, M., Pranjić, A., Dugalić, K., Ercişli, S. (2015): Use of in vitro propagation of 'Oblačinska' sour cherry in rootstock breeding. Turk J Biol, 39: 575-581. Tübita

doi: http://dx.doi.org/10.3906/biy-1412-85

6. Ebihara, K., Stryczewska, H.D., Mitsugi, F., Ikegami, T., Saka, T., Pawlat, J., Teii, S. (2012): Recent development of ozone treatment for agricultural soil sterilization and biomedical prevention. Przegląd Elektrotechniczny (Electrical Review), ISSN 0033-2097, R. 88 NR 6/2012

7. Hartmann, H., Kester, D. (1983): Plant propagation - principles and practices. Prentice Hall INC., Engelwood Cliffs, New Jersey, pp. 545-568.

8. Horvitz, S., Cantalejo, M.J. (2014): Application of ozone for the postharvest treatmentof fruits and vegetables. Crit. Rev. Food Sci. Nutr. 54, (3): 312-339.

doi: http://dx.doi.org/10.1080/10408398.2011.584353

9. Hrotkó, K., Magyar, L., Borsos, G., Gyeviki, M. (2014): Rootstock effect on nutrient concentration of sweet cherry leaves. J. Plant Nutr., 37(9): 1395-1409.

doi: http://dx.doi.org/10.1080/01904167.2014.911317

10. Yildirim, H., Onay, A., Tilkat, E., Aktürk, Z. (2011): Micropropagation of the apricot (Prunus armeniaca L.) cv. Hacıhaliloğlu by means of single node culture. Turk J Agric For, 35: 55-64, Tübitak.

doi: http://dx.doi.org/10.3906/tar-0904-2

11. Leifert, C., Waites, W.M., Nicholas, J.R. (1989): Bacterial contaminants of micropropagated plant cultures. Journal of Applied Bacteriology, 67, 353-361.

doi:http://dx.doi.org/10.1111/j.1365-2672.1989.tb02505.x

12. Leifert, C., Morrris, E.C., Waites, M.W. (1994): Ecology of microbial saprophytes and pathogens in tissue culture and field grown plants: reasons for contamination problems in vitro. Critical Reviews in Plant Sciences, 13(2): 139-183.

doi: http://dx.doi.org/10.1080/07352689409701912) 
13. Luna, C., Sansberro, P., Mroginski, L., Tarragó, J. (2003): Micropropagation of Ilex dumosa (Aquifoliaceae) from nodal segments in a tissue culture system. Biocell, 27(2): 205-12.

14. Luna, C., Collavino, M., Sansberro, P., Mroginski, L. (2009): Bacterial contaminationin Ilex dumosa (Aquifoliaceae) cultures: antibiotics treatment. Acta Hortic., 812: 97-102.

doi: http://dx.doi.org/10.17660/ActaHortic.2009.812.6

15. Mihaljević, I., Dugalić, K., Tomaš, V., Viljevac, M., Pranjić, A., Ćmelik, Z., Puškar, B., Jurković, Z. (2013): In vitro sterilization procedures for micropropagation of "Oblačinska" sour cherry. Journal of Agricurtural Science, 58(2): 117-126.

doi: http://dx.doi.org/10.2298/JAS1302117M

16. Miller, F.A., Silva, C.L.M., Brandão, T.R.S. (2013): A review on ozone-based treatmentsfor fruit and vegetables preservation. Food Eng. Rev., 5(2): 77-106. doi: http://dx.doi.org/10.1007/s12393-013-9064-5

17. Muna, A.S., Ahmad, A.K., Mahmoud, K., Abdul-Rahman, K. (1999): In vitro propagation of a semi-dwarfing cherry rootstock. Plant Cell Tisssue and Organ Culturae, 59: 203-208.

18. Murashige, T, Skoog, F. (1962): A revised medium for rapid growth and bioassays with tobacco tissue cultures. Physiol. Plant, 15: 473-97.

doi: http://dx.doi.org/10.1023/A:1006444925445

19. Sansberro, P.A., Rey, H.Y., Mroginski, L.A., Krivenki, M.A. (2001): Plant regeneration from llex spp. (Aquifoliaceae) in vitro. Biocell, 25: 139-146
20. SAS $^{\circledR}$ Software 9.3, (2002-2010., SAS Institute Inc., Cary, USA)

21. Sedlák, J., Paprštein, F., Erbenová, M. (2008): In vitro propagation of the $\mathrm{P}-\mathrm{HL}$ dwarfing sweet cherry rootstocks. ActaHorticulturae, 795: 395-400.

doi: http://dx.doi.org/10.17660/ActaHortic.2008.795.59

22. Schenk, R.U., Hildebrandt, A.C. (1972): Medium and techniques for induction and growth of monocotyledonous and dicotyledonous plant cell cultures. Canadian Journal of Botany, 50(1): 199-204.

doi: dx.https://doi.org/10.1139/b72-026

23. Šiško, M. (2011): In vitro propagation of Gisela 5 (Prunus cerasus $\times P$. canescens). Agricultura 8: 3134

24. Štolfa, I., Marić, S., Marić, S., Stanisavljević, A., Vuković, R., Śpoljarić, D., Varga, M. (2014): The impact of environmentally friendly postharvest treatments on the antioxidant activity of strawberry fruits during storage. Poljoprivreda/Agriculture/, 20(2): 23-28

25. Tančeva Crmarić, 0., Štambuk, S., Šatović, Z., Kajba, D. (2012): Micropropagation and genotypic diversity of wild cherry (Prunus avium L.) in the area of its natural distribution in Croatia. Croatian genetic society, 3rd congress of croatian geneticists - Krk: Croatian Genetic Society, 85-85 (ISBN: 978-953-57128-0-0)

26. Vujović, T., Ružić, Dj., Cerović, R. (2012): In vitro shoot multiplication as influenced by repeated subculturing ofshoots of contemporary fruit rootstocks. Hort. Sci. (Prague). 39, (3): 101-107.

27. Wysok, B., Uradziñski, J., Gomólka-Pawlicka, M. (2006): Ozone as an alternative disinfectant - a review. Pol. J. Food Nutr. Sci., 15/56(1); 3-8.

\section{STERILIZACIJA RAZLIČITIH TIPOVA EKSPLANTATA U MIKROPROPAGACIJI PODLOGA TREŠNJE CAB-6P I GISELA 6}

\section{SAŽETAK}

Istraživanja s ciljem pronalaženja učinkovitih sterilizanata, u svrhu veće automatizacije u uspostavi aseptične kulture tkiva in vitro, provedena su na podlogama trešnje CAB 6P i Gisela 6. Ispitivana su dva načina sterilizacije ( $\mathrm{NaOCl}$ i ozon $\mathrm{O}_{3}$ ), prateći stopu preživljavanja na tri tipa eksplantata; pupovi s primordijalnim lišćem, pupovi bez primordijalnoga lišća i nodijalni nelignificirani segment $s$ aksilarnim pupom. Ozon je rezultirao visokom stopom preživljavanja (od 57 do 93\%), bez obzira na vrstu eksplantata i varijante podloge. Uvođenjem cjelovitoga pupa bez destrukcije značajno je rezultiralo višom stopom preživljavanja (od 90 do $97 \%$ ). Rezultati ukazuju na potencijal sterilizacije ozonom inicijalnoga biljnoga materijala, ne samo kao površinskoga, nego i penetrirajućeg (subkutikularnog) agenta.

Ključne riječi: in vitro, CAB-6P, Gisela 6, sterilizacija, ozon

(Received on 8 October 2017; accepted on 15 November 2017 - Primljeno 8. listopada 2017.; prihvaćeno 15. studenoga 2017.) 